\title{
Osobní asistence ve školství jako podpůrný pomáhající prvek pro osoby se zdravotním postižením
}

\section{Personal Assistance in Education as a Supportive Element for People with Disabilities}

Ivana Havránková1, Česká abilympijská asociace, z.s., Pardubice

Zuzana Truhlářováa ${ }^{2}$ Ústav primární, preprimární a speciální pedagogiky, PdF UHK, Hradec Králové

\begin{abstract}
Abstrakt
Článek reaguje na aktuální zkušenosti při poskytování sociální služby osobní asistence u osob se zdravotním postižením ve školském zařízení v České republice. Cílem příspěvku je přiblížit reálný stav a fungování osobní asistence jako podpůrného prvku u dětí ve školském zařízení. Ćlánek popisuje sociální práci z pohledu zaměstnanců v přímé péči u klientů (osob se zdravotním postižením), zkušenosti zaměstnavatele při poskytování sociální služby ve školském zařízení. V popisu situace v sociální službě osobní asistence budou užity konkrétní př́klady z praxe.
\end{abstract}

\section{Klíčová slova}

osobní asistence, osoba se zdravotním postižením, inkluze

\section{Abstract}

The article responds to recent experience in the provision of a personal assistance social service for persons with disabilities in a school facility in the Czech Republic. The aim of the contribution is to approximate the real state and functioning of personal assistance as a support element for children in a school establishment. The article describes social work from the point of view of employees in direct care with clients (persons with disabilities), employer's experience in providing social services in a school facility. Specific practical examples will be used in the description of the situation in the personal assistance social service.

\section{Keywords}

personal assistance, person with a disability, inclusion

\section{Úvod}

V České republice je pojem inkluze, inkluzivní vzdělávání stále živé. Diskuse je vedena celospolečensky, a to nejen na odborné úrovni, ale i v široké veřejnosti. O tématu hovořílidé, kteří se pohybují v oblasti školství, v příbuzenských společenských vědních oborech, ale i lidé mimo něj. Cúlem inkluzivního vzdělávání je dostat maximum dětí do běžných škol. Umožnit do nich přístup i dětem, které by se do nich jinak těžko dostávaly, protože mají nějaké omezení obvykle ve formě zdravotního postižení. S touto myšlenkou se samozřejmě pojí řada otázek, at' už v rovině pozitivní, tak negativní.

Příspěvek reaguje na zkušenosti z praxe ve vybraných školských zařízení, kdy je vnímána sociální služba osobní asistence jako dobrý nástroj při inkluzi a uplatnění práv a potřeb dítěte se zdravotním postižením.

1 externí doktorandka FSV UCM v Trnave, vedoucí sociálních služeb Pracoviště: Česká abilympijská asociace, z.s., Pardubice; e-mailová adresa: ivana.havrankova@centrumkosatec.cz

2 Odborná asistentka, Ústav primární, preprimární a speciální pedagogiky, Pedagogická fakulta Univerzita Hradec Králové; e-mailová adresa: zuzana.truhlarova@uhk.cz 
Praktické kazuistiky uvedené v příspěvku vychází z praxe neziskové organizace Česká abilympijská asociace, z.s., Pardubice, která je poskytovatelem sociálních služeb (osobní asistence a sociální rehabilitace) a zároveň se profiluje jako sociální podnik.

\section{Jak lze vnímat inkluzivní vzdělávání ve spolupráci s osobní asistencí u osob s hendikepem?}

Termín „inkluze“ (z latinského „inclusio“) lze volně přeložit jako zahrnutí nebo přijetí do nějakého celku, tj. v př́padě osob se zdravotním postižením do běžné populace a v edukačním kontextu tedy i do běžné třídy/školy. Cílem inkluzivního vzděláváníje zajistit rovný přístup a rovné příležitosti ke vzdělávání všem jedincům se speciálními vzdělávacími potřebami, a to nezávisle na podobě jejich specifických potřeb. (Booth, Ainscow, 2007) Inkluzivní pedagogika je oborem pedagogiky, který se zabývá možnostmi optimální edukace dětí s postižením, narušením a ohrožením v podmínkách běžných škol a školských zařízení. Inkluzivní vzdělávání je praxe zařazování všech dětí do hlavního vzdělávacího proudu. V inkluzivní škole se neoddělují děti se speciálními vzdělávacími potřebami od ostatních dětí. Dochází ke společnému vzdělávání u dětí se zdravotním postižením, dětí jiného etnika, dětí talentovaných a nadaných, etnika i většinové společnosti. Pedagog zachovává rovnocenný přístup. Heterogenní složení supiny, kde je zachován individuální přístup, považuje inkluzivní model za přínos pro všechny žáky. (Kaleja, 2015)

Slowík (2007) s odkazem na další autory (Skutil, M., Zikl, P. a kol., 2011) uvádí, že v rámci inkluze tak dochází ke „splynutí“ tzv. minority (tj. jedinců se zdravotním postižením/se speciálními vzdělávacími potřebami) a majority (tj. intaktní populace/intaktních vrstevníků).

V rámci realizovaného výzkumu (Růžička a kol., 2020), (v projektu IGA/ IGA_Pdf_2019_024: Výzkum inkluze u jedinců se speciálními potřebami), provedené šetření mimo jiné ukázalo zásadní pozitivní posuny, ale také výrazná rizika ve školních poradenských činnostech. Autoři uvádí, že rovný přístup ke vzdělání je stále vizí a nikoli skutečností, jednou ze zásadních příčin tohoto stavu je konzervatismus našeho vzdělávacího systému, který mnohdy neochotně přijímá změny, a také časté změny legislativních norem, které nedávají jednoznačnou odpověd’ na řadu situací se společným vzděláváním spojených.

Pro úspěšné vzdělávání dětí, žáků a studentů se specifickými potřebami je dle Národního pedagogického institutu ČR žádoucí umožnit, zabezpečit:

- uplatňování principu diferenciace a individualizace vzdělávacího procesu při organizaci činností a při stanovování obsahu, forem i metod výuky,

- Všechna stanovená podpůrná opatření při vzdělávání žáků,

- při vzdělávání žáka, který nemůže vnímat řeč sluchem, jako součást podpůrných opatření vzdělávání v komunikačním systému, který odpovídá jeho potřebám a s jehož užíváním má zkušenost,

- při vzdělávání žáka, který při komunikaci využívá prostředky alternativní nebo augmentativní komunikace, jako součást podpůrných opatření vzdělávání v komunikačním systému, který odpovídá jeho vzdělávacím potřebám,

- v odůvodněných případech odlišnou délku vyučovacích hodin pro žáky se speciálními vzdělávacími potřebami nebo dělení a spojování vyučovacích hodin,

- pro žáky uvedené v § 16 odst. 9 školského zákona případné prodloužení základního vzdělávání na deset ročníků,

- formativní hodnocení vzdělávání žáků se speciálními vzdělávacími potřebami,

- spolupráci se zákonnými zástupci žáka, školskými poradenskými zařízeními a odbornými pracovníky školního poradenského pracoviště, v případě potřeby spolupráci s odborníky mimo oblast školství,

- spolupráci s ostatními školami. (online, NPI ČR | Inkluze v praxi - Co je inkluze, cit. [18082021]).

V praxi se ukazuje jako žádoucí součást multidisciplinárního týmu při inkluzivním vzdělávání služba osobní asistence. Je nezbytné, aby škola, zákonný zástupce dítěte komunikovali a nastavili úzkou spolupráci s poskytovateli sociálních služeb, tak, aby osobní asistent byl nápomocen a podporou při edukaci žáka, studenta v rámci celého vzdělávacího procesu. 


\section{Individuální vzdělávací plán žáka se specifickými vzdělávacími potřebami a vazba na individuální plánování osobní asistence}

Individuální vzdělávací plán zpracovává škola, vyžadují-li to speciální vzdělávací potřeby žáka. Individuální vzdělávací plán se zpracovává na základě doporučení školského poradenského zařízení. (Vyhláška č. 27/2016 Sb., o vzdělávání žáků se speciálními vzdělávacími potřebami a žáků nadaných)

Individuální vzdělávací plán obsahuje údaje o skladbě druhů a stupňů podpůrných opatření poskytovaných v kombinaci s tímto plánem, identifikační údaje žáka a údaje o pedagogických pracovnících podílejících se na vzdělávání žáka. V individuálním vzdělávacím plánu jsou dále uvedeny zejména informace 0

- úpravách obsahu vzdělávání žáka,

- časovém a obsahovém rozvržení vzdělávání,

- úpravách metod a forem výuky a hodnocení žáka,

- př́padné úpravě očekávaných výstupů vzdělávání žáka.

Individuální vzdělávací plán dále obsahuje jméno pedagogického pracovníka školského poradenského zařízení, se kterým škola spolupracuje při zajištování speciálních vzdělávacích potřeb žáka. (školský zákon)

\section{Asistent pedagoga, osobní asistent jako dobrý nástroj při inkluzivním vzdělávání}

Do celého procesu společně s pedagogem v konkrétních případech vstupuje asistent dítěte. Asistent pedagoga poskytuje podporu jinému pedagogickému pracovníkovi při vzdělávání žáka či žáků se speciálními vzdělávacími potřebami v rozsahu podpůrného opatření. Jak uvádí Čadová (2012), dítě se zdravotním postižením má své speciální potřeby, které vyžadují individuální přístup, a učitel není schopen se dítěti individuálně věnovat, když je ve třídě sám. Proto je klíčové, aby ve třídě byla zajištěna přítomnost další osoby, tedy asistenta pedagoga.

Asistent pedagoga, $\mathrm{k}$ jehož činnosti jsou stanoveny předpoklady³, zajištujuje zejména:

- př́mou pedagogickou činnost při vzdělávání a výchově podle přesně stanovených postupů a pokynů učitele nebo vychovatele zaměřenou na individuální podporu žáků a práce související s touto přímou pedagogickou činností,

- podporu žáka v dosahování vzdělávacích cílů při výuce a při přípravě na výuku, žák je přitom veden k nejvyšší možné míře samostatnosti,

- výchovné práce zaměřené na vytváření základních pracovních, hygienických ajiných návyků a další činnosti spojené s nácvikem sociálních kompetencí.

- pomocné výchovné práce zaměřené na podporu pedagoga zvláště při práci se skupinou žáků se speciálními vzdělávacími potřebami,

- pomocné organizační činnosti při vzdělávání skupiny žáků se speciálními vzdělávacími potřeba$\mathrm{mi}$,

- pomoc při adaptaci žáků se speciálními vzdělávacími potřebami na školní prostředí,

- pomoc při komunikaci se žáky, zákonnými zástupci žáků a komunitou, ze které žák pochází,

- nezbytnou pomoc žákům při sebeobsluze a pohybu během vyučování a při akcích pořádaných školou mimo místo, kde škola v souladu se zápisem do školského rejstř́íku uskutečňuje vzdělávání nebo školské služby,

- pomocné výchovné práce spojené s nácvikem sociálních kompetencí žáků se speciálními vzdělávacími potřebami.

Jednomu žákovi nelze doporučit současně více než jedno podpůrné opatření spočívající ve využití asistenta pedagoga.

Škola seznámí s individuálním vzdělávacím plánem všechny vyučující žáka a současně žáka a zákonného zástupce žáka, není-li žák zletilý, který tuto skutečnost potvrdí svým podpisem. Poskytování vzdělávání podle individuálního vzdělávacího plánu lze pouze na základě písemného informovaného souhlasu zletilého žáka nebo zákonného zástupce žáka.

Současně je velmi potřebné nastavit pro žáka se specifickými potřebami, kterému jsou poskytovány služby osobní asistence Individuální plán. (Zákon č.108/2006 Sb.) Individuální plán konkrétně zohledňuje potřeby dítěte. Dle definovaných potřeb dítěte a nepř́znivé sociální situace jsou nastaveny služby. Plán sestavuje sociální pracovník ve spolupráci s klíčovým pracovníkem dítěte, zákonným zástupcem dítěte.

3 Zákon č. 563/2004 Sb., o pedagogických pracovnících a o změně některých zákonů, v platném znění 
V praxi se poměrně často setkáváme se skutečností, kdy žák se specifickými potřebami nemá souběžně vypracován Individuální plán, který by byl součástí Individuálního vzdělávacího plánu, nebo by byl do něho zpracován. Stává se, že osobní asistent není seznámen s IVP žáka, nebot' tato propojenost není zákonnou povinností školy. V individuálním plánu jsou uvedeny cíle dítěte, kroky k naplnění cíle a způsob vyhodnocení individuálního plánu dítěte. V situacích, kdy probíhá osobní asistence u hendikepovaného dítěte či osobou zdravotním znevýhodněním ve škole, školského zařízení, mapují se potřeby dítěte v tomto prostředí, v procesu edukace.

V uvedeném kontextu lze souhlasit s Janišovou (1992), a to v otázce inkluzivního trendu při vzdělávání dětí se speciálními vzdělávacími potřebami, který úzce souvisí s modernizací přístupu k osobám se specifickými potřebami, s respektováním jejich individuálních potřeb a s uplatňováním jejich základních práv a svobod.

Pro tuto oblast spolupráce školy a poskytovatele sociálních služeb i v současné době vidíme určité rezervy.

\section{Př́lalady z praxe}

Dominika je 10leté dítě se zdravotním postižením, které má kombinovanou vadu (mentálníi tělesné postižení), DMO, k pohybu vyžaduje vozík, není schopna se dorozumět slovy, pouze výkřiky či zvuky. Dominika navštěvuje školní zařízení v Pardubickém regionu, kde vyžaduje pomoc ze strany osobní asistence v oblasti poskytování péče o vlastní osobu. Jedná se hlavně o přemístění zdravotně postiženého dítěte na cvičební vozík, který je univerzální pro celé zařízení. V průběhu cvičení se nejvíce o dítě stará její osobní asistentka, kterájí pomáhá provádět cviky správně, dle pokynů cvičícího. Dále se jedná o podání stravy a nápojů, při níž není Dominika schopna samostatné sebeobsluhy. Asistentka aktivně vkládá sousta do úst, bez této opory by se Dominika sama nenajedla. Při potřebě osobní asistentka jde s klientkou na toaletu, kde po celou dobu musí dělat vše za Dominiku (přemístit z vozíku na toaletu, utřít, obléct, vrátit na vozík a spláchnout, popřípadě poklidit, umýt ruce, dezinfekce). I v této rovině je Dominika plně závislá. Krmení a potřeba vlastní sebeobsluhy se opakuje několikrát denně. Tato klienta osobní asistence ve školském zařízení je plně závislá na asistentovi.

Nikola je dítě v raném věku, má mentální i tělesné postižení, kognitivní funkce jsou výrazně oslabeny. Nikola navštěvuje předškolní zařízení v Pardubicích. Běžná asistence u Nikoly probíhá následovně ráno si asistentka převezme dítě od rodiče u školního zařízení, asistentka převlékne Nikolu do tzv. „školkového“. Toto oblečení slouží k pohodlí dětí, aby mohly v průběhu celé školy lézt po zemi, plazit se, cvičit a rozvíjet se. Nikola nechodí a nemluví, veškerou manipulaci s dítětem realizuje asistentka, která je přítomna i při jiných aktivitách a je jediným zaměstnancem, který se dítěti plně a aktivně věnuje. Dorozumívání s Nikolou je očním kontaktem, či ukazováním, pleny jsou využívány celodenně. Asistentka zajištujuje osobní hygienu. Asistentka s Nikolou trénuje přetočení z lehu na zádech do lehu na břicho a plazení, pro lepší stabilitu těla.

\section{Problematika financování asistentů}

V současnosti se stále potýkáme s problémy financování osobního asistenta. Neziskový sektor je financován vícezdrojově, velkou část příjmů zajištují veřejné finance. Za odebrané služby a jejich čerpání je upraveno ve smlouvě o poskytování sociální služby ${ }^{4}$ Výše úhrady za osobní asistenci je stanovena vyhláškou ${ }^{5}$. V praxi poskytovatelé sociálních služeb často řeší náročné situace, kdy rodič dítěte, zákonný zástupce nemá dostatek finančních prostředků na zaplacení služby. Také se ukazuje složitá situace, kdy je dítě se zdravotním postižením hospitalizováno, nebo je nemocné, či na rehabilitačním pobytu a nenavštěvuje školu, pak klíčový osobní asistent nenaplní hodiny péče do stanoveného úvazku u poskytovatele. Je těžké v provozu služby tomuto zaměstnanci sociální služby hledat dočasně krátkou dobu jiného náhradního klienta v osobní asistenci.

4 ČESKO. Zákon č. 108 ze dne 31. března 2006, o sociálních službách. Sbírka zákonů ČR, 2006, částka 37, s 1257-1289. ISSN 1211-1244.

5 ČESKO. Vyhláška č. 505 ze dne 29. listopadu 2006, Vyhláška, kterou se provádějí některá ustanovení zákona o sociálních službách, uveřejněno v č. 164/2006 Sbírky zákonů, (2) Maximální vǵše úhrady za poskytování osobní asistence činí 130 Kč za hodinu, podle skutečně spotřebovaného času nezbytného k zajištění úkonů; pokud poskytování služby, včetně času nezbytného k zajištění úkonů, netrvá celou hodinu, výše úhrady se poměrně krátí. 
V podobné situaci je problematika financování pedagogického asistenta ze školského systému. V současné době chybí jednoznačná pravidla pro kooperaci školy, pedagogického asistenta, osobního asistenta, poskytovatele sociální služby, k jejich financování, a nastavení kompetencí.

\section{Závěr}

V České republice upravuje vzdělávání dětí, žáků a studentů se speciálními vzdělávacími potřebami školský zákon. Dítětem, žákem se specifickými potřebami se rozumí osoba se zdravotním postižením, osoba se zdravotním znevýhodněním, osoba se sociálním znevýhodněním. Vzdělávání dětí, žáků a studentů se speciálními vzdělávacími potřebami se uskutečňuje s pomocí podpůrných opatření, která jsou odlišná nebo jsou poskytována nad rámec individuálních pedagogických a organizačních opatření spojených se vzděláváním žáků stejného věku ve školách, které nejsou samostatně zřízené pro žáky se zdravotním postižením. Při akceptaci práv dítěte (z pohledu národní i mezinárodní legislativy) je zásadní hledisko a kritérium rovného přístupu a právo na vzdělávání. (Žolnová, 2019)

Pokud je respektováno výše uvedené pravidlo a je nastavena úzká spolupráce školy, učitele, asistenta pedagoga, osobního asistenta a dalších specialistů, která vychází v zájmu dítěte jak při edukačních činnostech, tak v rovině psychosociální v rámci vzdělávání zdravotně postižených dětí, pak můžeme hovořit o správném směru inkluze v České republice.

V současnosti v praxi vidíme různé úrovně a kvalitu připravenosti škol na inkluzivní vzdělávání. Současně nové trendy ve společnosti, smysl vzdělávání v kontextu společenských a technologických změn jsou podstatnou výzvou pro inkluzivní vzdělávání. Plošná inkluze a její nastavení ve školách nemusí být vždy ideálním řešením pro všechny žáky a studenty. S jistotou můžeme z praxe konstatovat, že pokud škola, školské zařízení v rámci vzdělávání osob se zdravotním postižením bude ve své činnosti aktivně využívat podpůnné nástroje včetně osobní asistence, bude tím zvyšovat kvalitu života osob s hendikepem, osob se zdravotním znevýhodněním.

\section{Literatura}

Booth, T., Ainscow, M. (2007) Ukazatel inkluze. Rozvoj učení a zapojení ve školách. Praha: Rytmus 0.s. Čadová, E. (2012) Metodika práce se žákem s tělesným postižením a zdravotním zneoúhodněním. Olomouc: Univerzita Palackého v Olomouci.

Janišová, M. (1992) Augmentatívna a alternatívna komunikácia. Ročenka Efety, 1992, 19-22.

Kaleja, M. (2015) (Ne)připravený pedagog a žák z prostředí sociální exkluze. Opava: Fakulta veřejných politik v Opavě.

Skutil, M., Zikl, P. a kol. (2011) Pedagogický a speciálně pedagogický slouník. Praha: Grada Publishing. Slowík, J. (2007) Speciální pedagogika. Praha: Grada.

Růžička, M. a kol. (2020) Speciální pedagog a další aktéři školního poradenského pracoviště ve společném vzdělávání. Olomouc: Univerzita Palackého v Olomouci.

Národní pedagogický institut České republiky, online NPI ČR | Inkluze v praxi - Co je inkluze, dostupné z http://www.inkluzevpraxi.cz/apivb/co-je-inkluze

Zákon č. 561 ze dne 10. listopadu 2004, o předškolním, základním, středním, vyšším odborném a jiném vzdělávání (školský zákon), Sbírka zákonů ČR, 2004, částka č. 190/2004.

Zákon č. 563 ze dne 10. listopadu 2004, o pedagogických pracovnících a o změně některých zákonů, Sbírka zákonů ČR, (2004), částka č.190/2004.

Vyhláška č. 27 o vzdělávání žákủ se speciálními vzdělávacími potřebami a žákủ nadaných, Sbírka zákonů ČR, (2016), částka č. 10/2016.

Zákon č. 108 ze dne 31. března 2006, o sociálních službách. Sbírka zákonů ČR, (2006), částka 37, s 1257-1289.

Žolnová, J. (2019). Osobná spokojnost', volný čas a finančná spokojnost' ako ukazovatele kvality života v prevýchovných zariadeniach na Slovensku av Pol'sku. Štúdie zo špeciálnej pedagogiky, 8(2), 127-135. 


\section{Informace o autorech}

\section{PhDr. Ivana Havránková}

Pracuje jako vedoucí sociálních služeb v Centru Kosatec, který zřizuje Česká abilympická asociace, z.s. Poslání spolku je především pomáhat lidem s hendikepem a bořit tak bariéry mezi světy zdravých a hendikepovaných.

Email: Ivana.havrankova@centrumkosatec.cz

\section{Mgr. Zuzana Truhlářová, Ph.D.}

Pracuje jako zástupkyně reditele a odborná asistentka na Ústavu primární, preprimární a speciální pedagogiky Univerzity Hradec Králové. Zabývá se problematikou formární a neformální sociální péče a kvality sociálních služeb.

Email: zuzana.truhlarova@uhk.cz

URL: https://orcid.org/0000-0002-3471-8657 